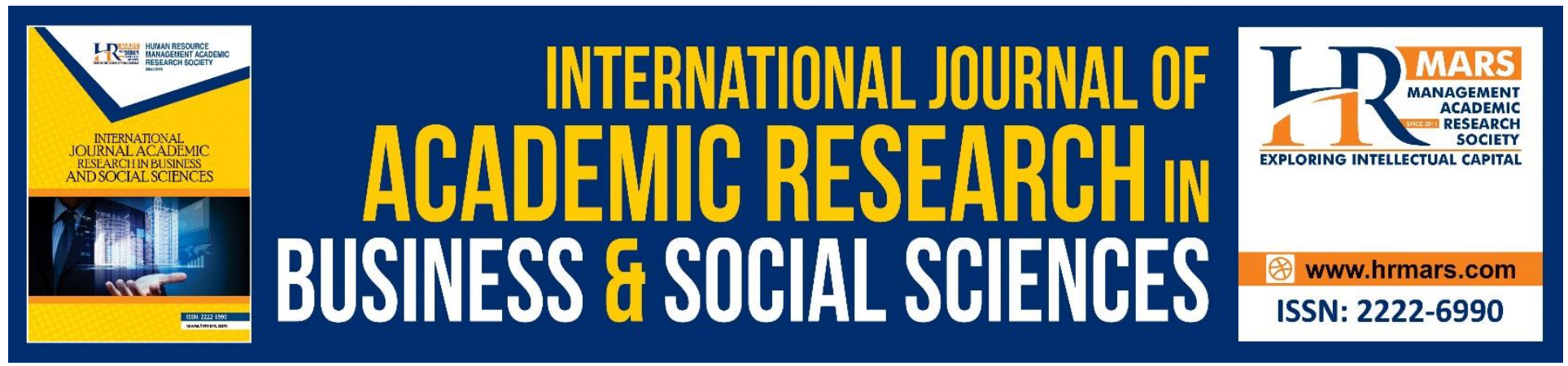

\title{
A Review of Job Challenges Factors for Women Engineer
}

\author{
Ummu Sakinah Subri
}

To Link this Article: http://dx.doi.org/10.6007/IJARBSS/v8-i9/4854

DOI: $\quad 10.6007 /$ IJARBSS/v8-i9/4854

Received: 25 July 2018, Revised: 27 August 2018, Accepted: 14 Sept 2018

Published Online: 21 Sept 2018

In-Text Citation: (Subri, 2018)

To Cite this Article: Subri, U. S. (2018). A Review of Job Challenges Factors for Women Engineer. International Journal of Academic Research in Business and Social Sciences, 8(9), 1450-1455.

Copyright: (C) 2018 The Author(s)

Published by Human Resource Management Academic Research Society (www.hrmars.com)

This article is published under the Creative Commons Attribution (CC BY 4.0) license. Anyone may reproduce, distribute, translate and create derivative works of this article (for both commercial and non-commercial purposes), subject to full attribution to the original publication and authors. The full terms of this license may be seen

at: http://creativecommons.org/licences/by/4.0/legalcode

Vol. 8, No. 9, September 2018, Pg. 1450 - 1455

http://hrmars.com/index.php/pages/detail/IJARBSS

JOURNAL HOMEPAGE

Full Terms \& Conditions of access and use can be found at

http://hrmars.com/index.php/pages/detail/publication-ethics 


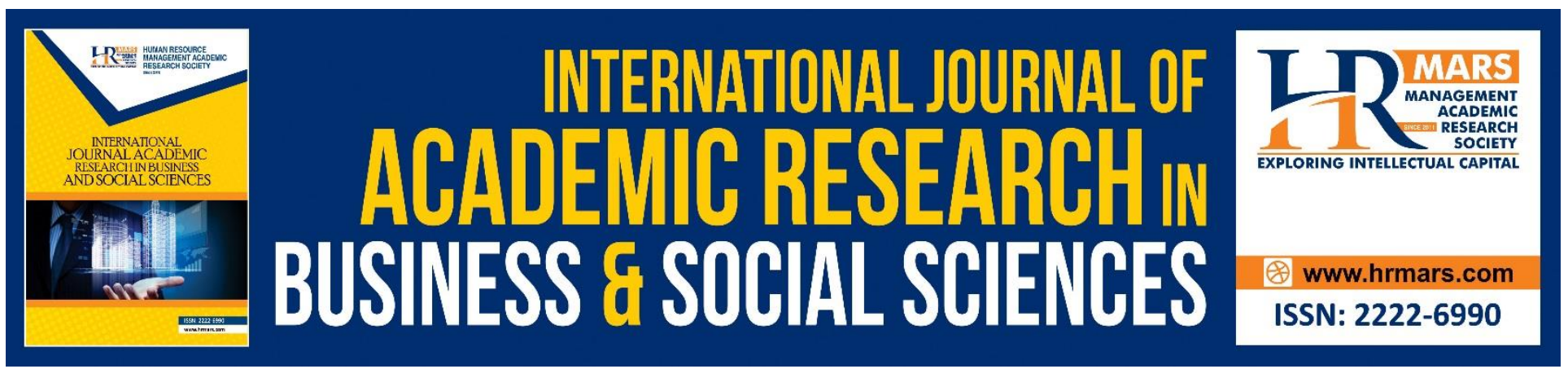

\title{
A Review of Job Challenges Factors for Women Engineer
}

\author{
Ummu Sakinah Subri \\ Ridzwan Che' Rus, Ramlee Mustapha, Zaliza Hanapi, Universiti Pendidikan Sultan Idris, Tg. Malim, \\ Perak. Malaysia
}

\begin{abstract}
Challenges are anything that prevents future movements from developing or making any progress or any incidents and conditions that make the career development difficult to move forward. This study focuses on the previous researches which investigate job challenges with the goal to gain more understanding about the issues or factors that restrained the career women from developing their career and instead chose to stop working. There are hundreds of past studies that can be chose to make a comparative result. Comparative Research Method had been used to analyse the data. The result of this comparative analysis between various past studies regarding career women and female engineers, the researchers found that there are 14 elements that became a conflict or challenges for women to keep working after marriage, which is leadership, gender discrimination, sexual harassment, work-life balance conflict (working-family), child care, safety, support, health, work environment, communication, salary, transportation, leaves, and women mentor. However, there are only three (3) elements that strongly influence women engineers to stop working after marriage, namely gender discrimination, child care, and work-life balance conflict. The results of this study can be used as guidelines in helping new researcher to further develop and broaden the research regarding women. This study also discussed suggestions for future studies to increase women workforce in various industries and this study also suitable to be used as a review study.
\end{abstract}

Keywords: Career Women, Female Engineers, Job Challenges, Job Challenges Factors

\section{Introduction}

The establishment of Human Resource Development (HRD) is to act as a producer or creator and as the supplier of the workforce, whether skilled or semi-skilled labours according to changes in technology and market as well as preparing skills needed in the future (Noorziah, Abdul Kadir, \& Dg Kamisah, 2015). In addition, the main responsibility of the Human Resource Development (HRD) is to provide flexible, agile, knowledgeable and with relevant skilled workforce (Nurazimah \& Yusri, 2013). 
In lines with these responsibilities, Jabatan Pembangunan Sumber Manusia Berhad or Human Resources Development Fund (HRDF) has taken an action by launching a special program HEARTS in 2013. HEARTS which means Housewives Enhancement Reactive Talent Scheme is set up to increase the numbers of female workers in the job market with the target group of women aged 25 to 60 years old. This program is created to attract women who are forced to quit their work due to the working hours that are not flexible with their responsibilities of managing the household. This is because, in the development of a career, women undeniably had to face with challenges, especially with the challenges that came after the marriage as what had been said by Suhaida and Mohd. Faizal (2014) that for women, in one hand had marriage and in another had a career, it was a test of their mental strength and resilience.

The Shah and Shah studies (2016), explain that from 51\% of women who are still working, there are still many who are facing problem in developing and improving their career status compared to men that have only $16 \%$ constraints. This is due to the factors such as job demands or expectations, tensions, stress at work, and family demands (Mardhiah et al., 2013). Therefore, a survey has been conducted to identify the factors of job challenges that have been a hindrance to these women engineers in continuing their work.

\section{Job Challenges Factors}

Challenges are anything that prevents future movements from developing or making any progress or any incidents or conditions that make the career development difficult to move forward (Brown \& Barbosa, 2001; Domenico \& Jones; 2006). Domenico \& Jones (2006) further stated that, some of the challenges or difficulties that they have faced, explained the gap between the women's abilities and their achievements or these obstacles can explain the constraints of women's career aspiration. Hindrances or obstacles are one of the important factors in the process of career development and the obstacles start since the period where the women were in school, college, and then working, and they will become more complex over time (Domenico \& Jones; 2006). Women often views challenged and conflicts as a barrier in the process of their career development (Albert \& Luzzo, 1999; Brown \& Barbosa, 2001; Luzzo \& McWhirter, 2001).

As a result of comparative analysis between various past studies regarding career women and female engineers, the researchers found that there are 14 elements that became a conflict or challenges for women to keep working after marriage, which is leadership, gender discrimination, sexual harassment, work-life balance conflict (working-family), child care, safety, support, health, work environment, communication, salary, transportation, leaves, and women mentor. However, there are only three (3) elements that strongly influence women engineers to stop working after marriage, namely gender discrimination, child care, and work-life balance conflict.

\section{Gender Discrimination}

Being exposed to the risky job environment or going into foreign places (off-site work) is something unavoidable when you chose to work in the technical industry. Faulkner (2016) explained that the challenges towards female engineers started when their abilities to perform off-site or going into foreign places is deemed inadequate by others. Furthermore, the nature of women itself, which is their nature to ask questions for every task that needs to be done had caused a mistrust by their 
employer towards their abilities compared to man's egoistic nature when it's come to ask and be allknowing (Smith, DiTomaso, Farris, \& Cordero, 2011; Lombardi, 2017). Additionally, even though women engineers want to prove their skills and abilities, some employers or co-workers, especially men may have doubts or hesitancy and sympathy to let women lead and do heavy tasks (Niemeier \& Gonzalez, 2014; Lombardi, 2017).

Discrimination towards the capabilities of women engineers had affected the job distributions, from the tasks of being an engineer to organizational management in which wage distribution is also affected due to the differences in responsibility where it is said to be lighter compared to men engineers (Collis, 2013; Faulkner, 2016; Umbach, 2016). In summary, the leadership of women engineers in carrying out their responsibilities has been always dubious and untrustworthy by others as Annunziata and Chase (2016) stated that gender discrimination is more towards the employer's lack of confidence in the administration or the leadership of the women itself.

\section{Child Care}

The responsibilities towards their child and to manage their career always causing the difficulties and challenges among women engineers whether to continue working or chose not to continue working (Unicef, 2010; Lath, 2010; Ibem, Anosike, Mosaku, \& Azuh, 2011). The issue with childcare is very complicated, especially involving the issue with the child safety and the suitability with the caretaker home, which often witness a case of child abuse or is not well-trained to handle and taking care of a child (Zanariah Noor, 2012). She further stated that the conventional opinion and the emphasis of women's responsibilities in the household that existed since before had caused the women more obstructed from seeking out job opportunities.

In addition, the lack of childcare facilities near or at work causes women engineers to choose to care for their own children, which eventually get them involved with informal and unpaid work sector (Perbadanan Pembangunan Pulau Pinang, 2013). So, child care also contributes to the stress and challenges towards women due to the difficulty in finding the most suitable caretakers or child nursery.

\section{Conflicts of Life Balance}

Life balance conflicts happened when the responsibilities cannot be performed fairly when demand is required both in professional and personal life. Challenges to carry and balance out various responsibilities can cause employees to experience fatigue, hard to concentrate, and difficult to gain common sense (Danielson et al., 2012). Fouad (2012) also explains that the majority of women engineers has a conflict of responsibilities when there are times they need to care for their child and at the same time to care for parents or family members who are old, while they also need to maintain their focus on the career. Each role has different claims and when the roles are overlapped with each other, various problems and issues will be faced and thus, creating a lot of pressure on these women (Singh, 2013; Mani, 2013; Yadav \& Yadav, 2014). Hence, these engineers need to balance all the claims and the pressures that came with the family and working responsibilities, to avoid and reduce family-work conflicts and achieve maximum level of life satisfaction. 


\section{Conclusion}

This study will be able to make new contributions in the literature by exploring the factors of job challenges among women engineers. In addition, the identification of these factors can be used as a guideline for the researcher and could be used in the future studies to be further developed in other career fields. Besides, through identifying this women conflict, it is possible to give an idea to a new researcher to study how to attract women's participation back into the job market. This continuous studies will create a closer relationship between the researchers and the society.

Models and theories have an important role in research, and even a model can provide guidelines for solving a restructuring or create a new system by referring to the presentation from the real world (Shafique \& Mahmood, 2010). Additionally, according to Yadav and Yadav (2014), with the understanding of matters or issues that do not meet the employee's standards will further attract the attention of employees and employers to have a better understanding of each other and thus, helping to remain working. Hence, the value of the elements that had been identified could be used as a guideline and help the newer researchers to build a new career model related to career.

\section{Correspondent Author}

Ummu Sakinah Subri

Fakulti Teknikal dan Vokasional

Universiti Pendidikan Sultan Idris

Email: usakinah.msubri@yahoo.com

\section{References}

Albert, K. A., \& Luzzo, D. A. (1999). The role of perceived barriers in career development: A social cognitive perspective. Journal of Counseling and Development, 77, 431-436.

Annunziata, M. \& Chase, K. (2017). Report of Engineering the Future: The Socio-Economic Case for Gender Equality.

Brown, S. G., \& Barbosa, G. (2001). Nothing Is Going To Stop Me Now: Obstacles Perceived By Low-Income Women As They Become Self-Sufficient. Public Health Nursing, Vol. 18, pp.364-372.

Collis, A. (2013). "The case for change: why engineering needs more women". The Guardian,from; https://www.theguardian.com/careers/women-in-engineering-pay-gap

Danielson B., Swatek E., Olaughlin M, Olischefski K., Geddert C. \& Hutchinson R. (2012). Flexible Work Arrangements

Domenico, D. M. \& Jones, K. H. (2006). Career Aspirations of Women in the 20th Century. Journal of Career and Technical Education, 22(2), Fall, 2006

Faulkner, W. (2016). Genders In/Of Engineering: A Research Report ESRC.

Fouad, A. N., Singh, R., Fitzpatrick, E. M., \& Liu, J. P. (2012). Stemming The Tide: Why Women Leave Engineering. Women in Engineering 2012 Report.

Ibem, E. O., Anosike, M. N., Azuh, D. E, \& Mosaku, T. O. (2011).Work Stress among Professionals in the Building Construction Industry in Nigeria. Australasian Journal of Construction Economics and Building. 
INTERNATIONAL JOURNAL OF ACADEMIC RESEARCH IN BUSINESS AND SOCIAL SCIENCES

Vol. 8, No. 9, Sept. 2018, E-ISSN: 2222-6990 @ 2018 HRMARS

Lath, S.K. (2010). A Study of the occupational stress among engineer. International Journal of Engineering and Science, 2 (2), 421-432

Lombardi, M. R. (2017). Women Engineers in Construction: The Feminization Possible and Gender Discrimination. Cadernos de Pesquisa v.47 n.163 p.122-145 Jan. / Mar. 2017.

Luzzo, D. A., \& McWhirter, E. H. (2001). Sex and ethnic differences in the perception of educational and career-related barriers and levels of coping efficiency. Journal of Counseling and Development, 79, 61-67

Mani, V. (2013). Work Life Balance and Women Professionals. Global Journal of Management and Business Research Interdisciplinary. Volume 13 Issue 5 Version 1.0 Year 2013

Niemeier, D.A., and Gonzalez, C. (2014). Breaking Into the Guildmasters' Club: What We Know About Women Science and Engineering Department Chairs at AAU Universities. NWSA Journal, 16, 157-171

Salleh, N. M., Rosline, A. K., Budin, D. K. A. (2015). Human Resource Management Roles \& Skills Shortages in Malaysian Organisations. Open Journal of Social Sciences, 2015, 3, 219-226. Biden, N. \& Kamin, Y. (2013). Implikasi Penjenamaan Semula Sekolah Menengah Vokasional (SMV) Kepada Kolej Vokasional (KV). 2nd International Seminar on Quality and Affordable Education (ISQAE 2013).

Perbadanan Pembangunan Pulau Pinang. (2013). Dasar dan Pelan Tindakan Penjagaan KanakKanak Pulau Pinang

Shafique, F. \& Mahmood, K. (2010). Model Development as a Research Tool: An Example of PAK-NISEA. Library Philosophy and Practice,2010.

Shah, V. \& Shah, P. (2016). Work - Family Balance - A Challenge For A Women. Indian Journal of Technical Education (IJTE). Special Issue for ICWSTCSC-2016

Singh, S. (2013). Work- Life Balance: A Literature Review. Global Journal of Commerce \& Management Perspective. Vol. 2(3) 2013: 84-91.

Smith, D. R., DiTomaso, N., Farris, G. F., \& Cordero, R. (2011). Favoritism, bias and error in performance ratings of scientists and engineers: The effects of power, status, and numbers. 45(September, 4/5): 337-358

Amin, S. M. \& Rameli, M. F. P. (2014). Fenomena Kekurangan Tenaga Kerja Wanita

Berpendidikan dan Berkemahiran di Malaysia. PERKEM ke-9 (2014) 269 - 277

Umbach, P. (2016). Gender Equity in the Academic Labor Market: An Analysis of Academic Disciplines. American Educational Research Association.

UNICEFF (2010). Bagaimana untuk Menubuhkan Taman Asuhan Kanak-Kanak di Tempat Kerja. Manual Pelengkap kepada PEKELILING AMALAN PERNIAGAAN TERBAIK 1/2010

Yadav, R. K. \& Yadav, s. S. (2014). Impact of work life balance and stress management on job satisfaction among the working women in heavy industry. International Letters of Social and Humanistic Sciences. doi:10.18052. www.scipress.com/ILSHS.26.63

Noor, Z. (2012). Isu-Isu Berbangkit Dari Hak Hadanah dan Hak Perwalian Anak. Jurnal Syariah, Jil. 20, Bil. 1 (2012) 123-144 